\title{
Self in Psychiatry, Psychology and Religion: Textual Analysis
}

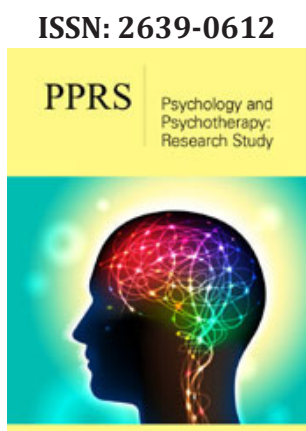

*Corresponding author: Ebrahim Khodadady, Ferdowsi University of Mashhad, Iran

Submission: 留February 02, 2021

Published: 㭗March 26, 2021

Volume 4 - Issue 5

How to cite this article: Khodadady E, Zahani Z H. Self in Psychiatry, Psychology and Religion: Textual Analysis. Psychol Psychother Res Stud. 4(5). PPRS. 000596. 2021. 2021. DOI: 10.31031/PPRS.2021.04.000596

Copyright@ Ebrahim Khodadady, This article is distributed under the terms of the Creative Commons Attribution 4.0 International License, which permits unrestricted use and redistribution provided that the original author and source are credited.

\author{
Ebrahim Khodadady ${ }^{1 *}$ and Zahra Hosseini Zahani ${ }^{2}$ \\ ${ }^{1}$ Ferdowsi University of Mashhad, Iran \\ ${ }^{2}$ Iran Language Institute, Iran
}

\begin{abstract}
This study explored how the three distinct fields of psychiatry, psychology and religion treated a "self" in terms of its constituting features and cognitive taxa. To achieve the objective the micro structural approach of schema theory was applied to the representative texts of these fields by specifying and analyzing all the tokens of "self" and its derivatives. When statistical tests were applied to the data it was found that psychiatry, psychology and religion differed significantly from each other in the number of tokens. The reduction of tokens to types and the assignment of types to their hierarchically established cognitive taxa showed that religion treated the "self" more comprehensively and objectively than psychiatry and psychology did. The results are discussed in terms of the cognitive taxa to which psychiatry, psychology and religion assign the "self" to.
\end{abstract}

Keywords: Self; Schema theory; Constituting features; Cognitive taxa

\section{Introduction}

"Self" is one of the key mental concepts or schemata addressed in psychiatry, psychology and "religion. No scholar has, however, examined how these three fields address it. This study was, therefore, designed to explore the "self" in psychiatry, psychology and "religion by resorting to schema theory and textual analysis. The theory has been applied to experiences a given "self" gains either macro structurally or micro structurally. The former is defined in broad and vague statements such as "the fundamental elements upon which all information processing depends" [1]. In spite of its dominance in the literature, the macro structural approach of schema theory has not been operationalized successfully by any scholar for two main reasons. First, "there is no generally agreed upon formal definition of a schema" [2]. Secondly, it has failed to describe cognitive processes such as reading comprehension ability and its assessment via multiple choice items [3,4]. For these reasons Khodadady [5] developed its micro structural approach and defined a schema as any concept realized in a word or phrase, syntactic or semantic, closed or open, syntagmatic or paradigmatic, which can stand by itself or combine with other concepts to produce an idiosyncratic image in the mind of a given person. This image has a direct relationship with the person's experiences with the concept gained through its application with other semantically and syntactically related concepts. Schemata are idiosyncratic because individuals differ from each other in terms of their experiences (p. 111).

Table 1: Hierarchically related cognitive taxa of "human" and "dog" and their features.

\begin{tabular}{|c|c|c|c|}
\hline Taxa & Human & Dog & Constituting Features \\
\hline Domain & Organism & Organism & Human, dog, plant, microorganism \\
\hline Kingdom & Animalia & Animalia & Human, dog, wolf, fox, ape, horse, fish, ants \\
\hline Phylum & Chordata & Chordata & Human, dog, wolf, fox, ape, horse, fish \\
\hline Class & Mammalia & Mammalia & Human, dog, wolf, fox, ape, horse \\
\hline Order & Primates & Carnivora & Human, dog, wolf, fox, ape \\
\hline Family & Hominidae & Canidaex & Dog, wolf, fox \\
\hline Genus & Homo sapiens & Canis & Dog, wolf \\
\hline Species & Sapiens & Familirais & Human, dog \\
\hline
\end{tabular}


The definition above provides a strong rationale to study a "self" objectively. It can also be related to other schemata by assigning it to hierarchically related levels [6]. As a representative text of psychiatry, "Kaplan \& Sadock's Synopsis of Psychiatry: Behavioral Sciences/Clinical Psychiatry" [7], for example, places the schema "self" in certain phrases, clauses, sentences, subheadings, headings, and chapters which form its hierarchically related linguistic levels. Along with linguistic levels, a "self" can be assigned to biological levels or taxa. As the first botanist, Linnaeus [8], for example, established eight taxa into which he placed his schemata of interest, i.e., species, genus, family, order, class, phylum, kingdom, and domain. Azabdaftari [9] followed Linnaeus' taxonomy and presented the schema of "dog" in the biological taxa of familirais, canis, canidaex, carnivore, mammalian, chordate, animalia, and organism (Table 1).

Along with "dog", the schema "human" has been placed in the biological taxa presented in Table 1 above to show how they converge and diverge from each other on their constituting features. As can be seen, there are no family taxa for "human" other than "their fossil ancestors (fossil hominids) in the genus" (Oxford Dictionary of Science, 2005, p. 398). This vary application of micro structural approach of schema theory (MICAST) to the study of "human" and "dog" does, therefore, reveal a very important fact, i.e., science has been unable to provide living features for humans at "Hominidae" and "Homo sapiens" taxa. In other words, humans differ from other organisms such as "dogs" in not having any genus and family. A "self" as a human also differs from a "dog" in a number of features whose cognitive taxa have already been established via the MICAST. It is, for example, the "self" who motivates itself as a sighted [10] and blind [11] individual to learn the English language not only in institutes but also in public boarding schools [12], develops an identify for itself in the language [13], relates it to its religious orientation [14] and spirituality [15] and translates dentistry texts to other languages [16].

In addition to specifying the cognitive taxa of various features of a "self", the MICAST allows researchers to study it across texts. Three individuals as distinct "selves", for example, wrote the textbooks "World English" [17], "Top Notch" [18], and "American English File" [19] and claimed that they had adopted a global approach toward English. Khodadady and Shayesteh's [20] analysis of the textbooks, however, showed although these selves aimed to "address the language learners anywhere in the world, their references to the inner circle [or English speaking] countries and native speakers of English still surpass the outer and expanding circle countries, [where English is spoken as a second or foreign language]" (p. 604). Similar to the three textbooks addressing a common schema such as adopting "a global approach toward English" [20] three modern texts representing psychiatry, psychology and religion were chosen in this study to be analyzed via the MICAST because they addressed a "self" as their common schema. These texts were then subjected to statistical analyses to answer the following four research questions.

1. How many words do the representative texts of psychiatry, psychology and religion employ to address "self"?
2. Do the texts differ in the number of times they use the word "self"?

3. What words of "self" do the texts share?

4. What taxa of "self" do psychiatry, psychology and religion converge on and diverge from?

\section{Methodology}

\section{Text}

Three texts were analyzed in this study. The first, i.e., the $11^{\text {th }}$ edition of "Kaplan \& Sadock's Synopsis of Psychiatry: Behavioral Sciences/Clinical Psychiatry", according to its authors Sadock, Sadock [7], is used "both in the United States and around the world" (p. iv). The users have not only been "psychiatrists and nonpsychiatric physicians, medical students, psychologists, social workers, psychiatric nurses, and other mental health professionals such as occupational and art therapists, among others" but also "nonprofessionals" who need "an authoritative guide to help them collaborate in the care of a family member or friend with mental illness." The PDF file of this text consisted of 1496 pages, 37 chapters, and a glossary of terms relating to signs and symptoms and index. The second text, the ninth edition of "Abnormal Psychology," according to its author, Comer [21], approaches clinical psychologists as "clinical scientists ... who gather information systematically to detect, assess, and treat abnormal patterns of functioning" (p. 2) in a "self". It comprises 852 pages, 19 chapters, Glossary G-1, References R-1, Credits C-1, Name Index NI-1, and Subject Index. Similar to Sadock, Sadock, and Ruiz's (2015) text, "Abnormal Psychology," is used by mental health professionals such as psychiatric nurses in the United State and around the world.

The third text, the Quran, is read by "over two billion Muslims worldwide" [22] as their Holy Scripture. A considerable number of individuals are also "drawn to it for diverse reasons" [23]. Khodadady and Dastgahian [24], for example, developed a religious orientation scale on its 57 verses. The Quran consists of 114 chapters or surahs and 6348 verses or ayat, the plural of ayah. [The number of ayat counted in this study includes the first ayah of the first surah (Q1:1) i.e., "In the Name of Allah, the All-Compassionate, Ever-Compassionate" [25] as the first ayah of all other surahs except the ninth as well.

\section{Procedures}

The PDF files of "Kaplan \& Sadock's Synopsis of Psychiatry: Behavioral Sciences/Clinical Psychiatry" [7] and "Abnormal Psychology" [21] were analyzed as regards the number of times the word "self" and its derivatives such as "myself" and "selfefficacy" were used in them. To this objective, with the exception of the chapters and glossaries, all other sections of the two texts were removed resulting in the reduction of 1496 and 852 to 1417 and 683 pages, respectively. The search was conducted through the Find command of the Adobe Acrobat DC and the results were saved for the textual analysis of data. 
In addition to the two English PDF files of psychiatry and psychology, the Arabic Word file of the Quran was searched for the word "nafs" as well as the words of which it formed a part. These words provide the Quranic equivalents of English schema "self" [26] used as their root. The Arabic Word file of the Quran was analyzed because its English translators have offered different equivalents for "nafs" due to its linguistic morphs. In Ayeh Q89:27, for example, it is translated as "human being" [27] and "soul" [2830]. Searching for the word "nafs" in the Arabic text of the Quran necessitated looking for 40 words formed from the root "nfs" in this particular Holy Scripture. This procedure had to be followed because the written Arabic language employs diacritics instead of vowels represented by English letters a, e, i and o in its orthography, the three words "nafs", "nafsin" and "nafsun" do, for example, represent "self" in English. The search was conducted manually and one by one by utilizing the Find command of the Microsoft Word.

In addition to the Arabic text of the Quran, its English translations rendered by Al-Hilali and Khan [31], Asad [27], Nasr et al. [29] and Yusuf Ali [30] were consulted as regards their translation of "self" and its derivatives. Upon specifying their English equivalents they were searched in each and all translations one by one. The multiple searches allowed the researchers to avoid their untoward omission in the process of textual analysis. Upon forming a complete list of the word "self" and its derivatives in English, their plural forms were changed to singular so that they would not be counted as two different words as the SPSS does. The words "selves" and "selfies" were, for example, changed into their singular forms, i.e., "self" and "selfie", respectively because the SPSS counts them as different types of word. Since words such as "one-self" and "oneself" are also counted as two different words in the SPSS the former was also replaced with the latter as the most frequently used form in English texts.

\section{Data Analysis}

The three printed texts "Kaplan \& Sadock's Synopsis of Psychiatry: Behavioral Sciences/Clinical Psychiatry" [7], "Abnormal Psychology" [21], and the Quran were treated as three values of a nominal or categorical variable. The word "self" and its derivatives used in each and all texts were considered as the cases of values. For operationalising the words Bussmann [32] was followed and the "blank spaces" (p. 1285) appearing before and after the "self" and its derivatives were used to identify and separate them from the other words constituting the texts. Upon collecting the word "self" and its derivatives they were subjected to chi-square analysis two times, once as tokens and another time as types. The word "self" which is provided as one of the two English equivalents for the Arabic "nafs" by Buckwalter [26], for example, is a word type contributing to a 30-million word corpus of spoken and written Arabic texts. It had a token or frequency of "52702" (p. 12) in the corpus upon which Buckwalter and Parkinson compiled their text. The statistical analyses of tokens and types of the "self" and its derivatives were carried out through IBM SPSS Statistic 24.

\section{Result}

Subjecting the collected data to descriptive statistics answered the first research question, i.e., the three texts representing the fields of psychiatry, psychology and religion consisted of 3550 tokens of self. Out of these tokens, 2226, 1092 and 232, contributed to the three fields, respectively. The data were also subjected to chisquare tests to answer the second research question. The results indicated a significant difference in the number of "self" tokens $\left(X^{2}=1477.908, d f=548, p<.0001\right)$ used in psychiatry, psychology and religion (Table 2). For distinguishing the word "self" from its derivatives their tokens were reduced to types (see Appendix for the complete list of "self" types). It resulted in identifying 279 words among which "themselves" had the highest token, i.e., 726. The reduction of tokens to types also showed that "self" contributes to three more fields i.e.,

Table 2: Chi-square tests of "self" tokens in psychiatry, psychology and religion.

\begin{tabular}{|l|c|c|c|}
\hline & Value & Df & $\begin{array}{c}\text { Asymptotic Significance } \\
\text { (2-Sided) }\end{array}$ \\
\hline Pearson Chi-Square & $1477.908^{\mathrm{a}}$ & 548 & 0.000 \\
\hline Likelihood Ratio & 1423.920 & 548 & 0.000 \\
\hline N of Valid Cases & 3550 & & \\
\hline
\end{tabular}

a. 746 cells $(90.4 \%)$ have expected count less than 5 . The minimum expected count is .07 .

1. psychiatry and psychology,

2. psychiatry, psychology and religion, and

3. psychology and religion (Table 3).

Table 3: Fields generated by reducing tokens of "self" and its derivatives to types.

\begin{tabular}{|c|c|c|}
\hline Fields & $\begin{array}{c}\text { \# of } \\
\text { Types }\end{array}$ & Self Types \\
\hline Psychiatry & 167 & $\begin{array}{r}\text { self-abandonment, self-abusive, } \\
\text { self-accepted, ... }\end{array}$ \\
\hline Psychiatry \& psychology & 73 & False self, true self, ... \\
\hline $\begin{array}{c}\text { Psychiatry, psychology \& } \\
\text { religion }\end{array}$ & 7 & $\begin{array}{c}\text { Herself, himself, myself, ourselves, } \\
\text { self, themselves, yourself }\end{array}$ \\
\hline $\begin{array}{c}\text { Psychology } \\
\text { Psychology \& Religion }\end{array}$ & 1 & $\begin{array}{c}\text { self-actualize, self-actualized, } \\
\text { self-anger, ... }\end{array}$ \\
\hline Religion & 4 & $\begin{array}{c}\text { Yourselves } \\
\text { monotheistic, the polytheistic self, } \\
\text { the self-theistic }\end{array}$ \\
\hline
\end{tabular}

The reduction of 3550 tokens of "self" and its derivatives to 279 types also answered the third question, i.e., the texts representing psychiatry, psychology and religion share only seven types, i.e., herself, himself, myself, ourselves, self, themselves, and yourself. Out of 279 "self" types, psychiatry and psychology share $73(26.3 \%)$ because they largely address the features of instincts taxa such as "self-esteem", "self-report", and "self-injurious" than the features of its other taxa (Table 4). Religion does, however, diverge from psychiatry and psychology because it assigns a "self" to five other cognitive taxa which are exclusive to it, i.e., psyche, the self-theistic, the polytheistic, the practicing monotheistic, and God's self. These findings answer the fourth research question, i.e., psychiatry, 
psychology and religion converge on three taxa of body, instincts and cognition and emotion but diverge on the remaining taxa. While psychiatry and psychology assign the "self" to two higher humanistic taxa, i.e., false self and true self, religion assigns it to five higher taxa whose constituting features depend on denying or following God. These taxa will be discussed based on their features.

Table 4: Cognitive taxa of "self" in psychiatry, psychology and religion and their features.

\begin{tabular}{|c|c|c|c|}
\hline Taxa & Psychiatry \& Psychology & Religion & Constituting Features \\
\hline Domain & True self & God's self & all-compassionate, ever-compassionate, almighty, the wise, the \\
knower, the hearer.
\end{tabular}

\section{Discussion}

Psychiatry, psychology and religion do address a "self" at its lowest cognitive taxon, i.e., body. As one of the main features of body, the "heart", for example, occurs for the first time in their representative texts in the sentences "The parasympathetic system slows the heart rate and begins the process of digestion", "Endocrine glands, located throughout the body, work along with neurons to control such vital activities as growth, reproduction, sexual activity, heart rate, body temperature, energy, and responses to stress" [21] and "God has sealed their hearts and their hearing. Upon their eyes is a covering, and theirs is a great punishment" (Q2:7), respectively. [The English Quranic ayat are based on Nasr et al. [29] translation if not specified otherwise.

As can be seen in the quotations above, psychiatry approaches the body of a "self" from a purely physiological perspective whereas psychology extends it to "stress" as a feature of the third taxon of "self", i.e., cognition and emotion. (For example, being in an unknown situation alone makes a "self" stressful and its heart starts beating fast.) Religion, however, relates the heart of the body described in Q2:7 not only to cognition, i.e., deafness and blindness (e.g., Q2:118) and emotions such as "fear and grief" (e.g., Q2:38) but also to other cognitive taxa of "self". It does, for example, announce that only the practicing monotheistic "self" does not grieve because it knows that God is with it (Q9:40). Due to the importance of body as the lowest taxon of "self", it will be discussed in more details, albeit briefly.

\section{The first taxon of "self": Body}

Psychiatry acknowledges the uniqueness of body as the first cognitive taxon of "self" when it addresses it for the first time by focusing on one of its constituting features in the sentence "Although the complexity of the human brain is daunting compared with other organs of the body [italics added], progress can only be made if one approaches this complexity consistently, methodically, and bravely". One of its brave methods was, for example, to make the unsubstantiated claim that "The human brain clearly evolved [italics added] from the brain of lower animal species, allowing inferences to be made about the human brain from animal studies" (p. 1). If the claim was clear enough Mr. Bell could have taught Human language to his "dog" as a "self" based on whom Pavlov could build his theory of conditioning! Instead of employing the brain to address body, psychology opts for mind when it brings up the body for the first time in the sentence, "[People in prehistoric societies] viewed the human body [italics added] and mind as a battleground between external forces of good and evil". It relates this superstitious view with religion writing, "The Bible, for example, describes how an evil spirit from the Lord affected King Saul and how David feigned madness to convince his enemies that he was visited by divine forces" (p. 5). Psychology employs the Bible interchangeably with Old Testament (OT) without even bothering to provide the exact verse upon which it builds its arguments, i.e., "And it came to pass on the morrow, that the evil spirit from God came upon Saul, and he prophesied in the midst of the house: and David played with his hand, as at other times: and there was a javelin in Saul's hand" (Samuel 18:10). Psychology quotes religion unscientifically in order to render it superstitions without acknowledging that the text of OT "was developed [by unknown authors] in pre-Christian times" [33]. As the latest text of religion, the Quran categorically rejects claims such as evils coming from God. It condemns the forgers of such claims, i.e. the self-theistic and polytheistic selves, and asks its readers to "see how they fabricate lies against God" (Q4:50). Such fabrications have been made by "the Jews by their attribution of lawgiving powers to the great Talmudic scholars, whose legal verdicts are supposed to override, if need be, any ordinance of the scriptures [italics added]" [27]. In direct opposition to these fabrications, the Quran announces repeatedly that not evils but "the most beautiful names belong to God (Q7:180, 110; Q20:8; Q59:24).

The first of the most beautiful names is Allah whose token is the highest, i.e., 2808, simply because the whole Quran was revealed not only to expose the lies fabricated against God in the name of religion (Q4:50) but also to remind humans that every single "self" must know and follow none but God because no one but the "self" itself will be held responsible for what it has earned in this 
world (Q74:38). The second most frequent name in the Quran is the All-Compassionate ( $\mathrm{t}=167$ ) because Allah is "the one and only God" (Q2:255) who is compassionate to all His creatures, including those who do not believe in Him, and provides them with safety and food in this world $(\mathrm{Q} 2: 126)$. While psychiatry and psychology deliberately avoid addressing the nature of body as the first taxon of "self" religion relates it directly to that of God, i.e., "Set thy face to religion as a haniff, in the primordial nature from God upon which He originated mankind-there is no altering the creation of God; that is the upright religion, but most of mankind know not" (Q30:30). In other words, God has set human "self" apart from other creatures by giving it a "body" capable of receiving His soul or psyche, i.e., the fourth taxon of "self" (to be discussed shortly). For this very reason science has not been able to find any living biological genus and family for human "self" than the so-called fossils!

\section{The second taxon of "self": Instincts}

Psychology basically views instincts for the first time from a biological perspective and supports the view through various means such as presenting the photo of a mouse standing and smelling a wide awake cat with no fear. The mouse behaves fearlessly because "Scientists at Tokyo University used genetic engineering to switch off this rodent's instinct to cower at the smell or presence of cats (p. 147). Psychiatry, however, questions such a stance by resorting to experiences a "self" gains in its life, i.e. After the development of the topographical model, Freud turned his attention to the complexities of instinct theory. Freud was determined to anchor his psychological theory in biology. His choice led to terminological and conceptual difficulties when he used terms derived from biology to denote psychological constructs. Instinct, for example, refers to a pattern of species-specific behavior that is genetically derived and, therefore, is more or less independent of learning. Modem research demonstrating that instinctual patterns are modified through experiential learning, however, has made Freud's instinctual theory problematic [7].

In other words, while psychology primarily attempts to approach instincts biologically psychiatry extends it to the society in which a "self" lives. Though the latter sets instincts in a more comprehensive context than the former does as they approach instinct for the first time in their representative texts, both assign a passive role to the "self". Psychiatry, for example, supports the passiveness or helplessness of "self" in fulfilling its instincts by quoting psychoanalysts. Klein [for example] viewed projection and introjection as the primary defensive operations in the first months of life. Infants project derivatives of the death instinct into the mother and then fear attack from the "bad mother," a phenomenon that Klein referred to as persecutory anxiety [7]. As can be seen in the quotation above psychiatry acknowledges infant's cognition in terms of projection and introjection and emotion in terms of its fear and anxiety. Along with psychology it also recognizes the infant's ability to fulfill its instinct of death. They do not, however, assign any of these taxa to the infant's false or true "self". Instead, they hold the mother responsible for the infant's development of these taxa as an implicitly passive "self".
In contrast to psychiatry and psychology, religion assigns an active role to "self" from its earliest existence. Upon the completion of its body in the mother's womb God blows His own soul into it (Q32:9) and makes all angels other than Satan submissive to its will (Q7:11). Although religion agrees with the instincts specified by psychiatry and psychology, it brings up another instinct unique to human "self", i.e., "knowing and choosing the right or wrong" (Q91:8). Based on this instinct it determines which higher taxa of itself it prefers to be identified with, i.e., the self-theistic, the polytheistic or the practicing monotheistic. These taxa will be discussed after analyzing the third taxon of the "self".

\section{The third taxon of "self": Cognition and emotion}

Psychiatry and psychology do consider cognition and emotion as a taxon of "self". They do not, however, address its ontology. In contrast religion traces their origin in God. It announces that since God Himself knows everything (Q2:33), i.e., cognition, and is All-Compassionate to all his creatures in this world (Q1:3), i.e., one of his many emotions, He not only transfers his cognition and emotions to human "self" by blowing His soul into it (Q15:29) but also teaches what it needs to know and feel (Q2:31). Similar to instincts, psychiatry and psychology stay mute as regards how a "self" develops its cognition and emotion. Religion, however, offers language as a unique means through which the "self" not only receives but also develops its own cognition and emotion. Religion also emphasizes that it is God who teaches the language to the "self" (Q55:4). Furthermore, religion offers learning language, i.e., names, as a species-specific ability by relating an event in the history of its creation. When all creatures referred to as angels in the Quran objected to God's command regarding their submission to human "self" as His vicegerent on the earth, He taught both the "self" and the angels the names of everything including all actions and feelings representing cognition and emotion and then held a test (Q2:31). When only the human "self" passed the test, the angels acknowledged its superiority (Q2:30) and submitted to it by prostration (Q2:34), Had Alexander Graham Bell read the Quran he would not have "tried to teach his dog how to talk" [21]!

\section{The fourth taxon of "self": Psyche}

Although modern psychiatry and psychology both owe their names, if not their existence, to "psyche", their representative texts have paid the least attention to it. While psychology, for example, does not employ "psyche" even once, psychiatry reveals its indecisiveness as regards what exactly it stands for. Though it employs it ten times, psychiatry defines it parenthetically as "soul" and "mind" when it employs "psyche" for the fourth time, i.e., "The term psychosomatic is derived from the Greek words psyche (soul) and soma (body). The term literally refers to how the mind affects the body" [7]. The utilization of "psyche" at its fifth occurrence, however, shows that psychiatry is not content with using "soul" and "mind" interchangeably with "psyche" and does, therefore, keep repeating it till its ninth occurrence. Surprisingly, however, psychiatry prefers "behaviour" to "psyche" when it uses it for the last time in its representative text, i.e., "behavior: Sum total of the 
psyche [italics added] that includes impulses, motivations, wishes, drives, instincts, and cravings, as expressed by a person's behavior or motor activity".

In contrast to psychiatry and psychology, religion equates "psyche" with God's soul. Because of having God's soul in itself, a "self" acquires a unique position in this world, i.e., being His only vicegerent on the earth (Q2:30; Q6:165; Q10:14; Q35:39), provided that it behaves as God does Himself. Two of these behaviours are specified below when God addresses one of His prophets. O David! Truly We have appointed thee as a vicegerent upon the earth; so, judge among the people with truth and follow not caprice, lest it lead thee astray from the way of God. Truly those who stray from the way of God, theirs shall be a severe punishment for having forgotten the Day of Reckoning. (Q38:26). As Q38:26 quoted above shows, religion partly agrees with psychiatry in equating "the sum total of the psyche" with behavior. It does, however, diverge from psychiatry on the type of behaviour they accept as "psyche". While psychiatry defines behaviour in terms of "impulses, motivations, wishes, drives, instincts, and cravings", i.e., caprices, religion defines it in terms of truth (Q38:26), i.e., collecting and analyzing as many facts as possible before judging among the people. In fact, whether a "self" rejects or follows the truth determines its fifth, sixth and seventh taxa, i.e., the self-theistic, the polytheistic, and the practicing monotheistic.

\section{The fifth taxon of "self": The self-theistic}

Neither psychiatry nor psychology approaches "self" from a theistic perspective. Religion does, however, define an individual as self-theistic when he considers itself to be other selves' lord most high (Q79:24), rejects the facts as false (Q8:54), and does the opposite of what God commands it to do (Q20:24; Q79:17). Pharaoh, for example, was a self-theist who enslaved the Israelites because he needed slaves. Instead of treating and paying the Israelites properly for what they did, he forced them to serve him as their lord most high (Q2:49). He also killed their sons (Q14:6) because he feared the Israelites might increase in number and revolt against him. Former President Trump is a living example of a self-theist who encouraged his supporters to occupy the Capitol Hill because he thought that his presidential rival and his supporters had cheated in the presidential election. Trump insisted on his false claim of fraudulent election in spite of the fact that no cheating could be verified by any court of law, bringing about the death of several people. Psychiatry and psychology represented by the texts analyzed in this study do not; however, seem to treat self-theists such as former President Trump as individuals who suffer from mental disorder.

\section{The sixth taxon of "self": The polytheistic}

Neither psychiatry nor psychology recognizes the polytheistic as a taxon of "self". They do, however, accept "false self" whose features are fairly close to those of the polytheistic. Psychiatry, for example, characterizes "false self" in one single sentence, i.e., "adolescents must achieve an Identity that allows them to become separate from their parents, for mental health and adult development cannot evolve through a false self". Similar to adolescents with no identify, the polytheistic exploit anyone including their parents to satisfy their caprices. Following psychiatry, psychology employs one single sentence throughout its representative text to define "false self". Its sentence is, however, more informative than that of psychiatry because it defines the "false self" with reference to "true selves", i.e. According to Laing's [34-36] existential principles, human beings must be in touch with their true selves in order to give meaning to their lives. Other people's expectations, demands, and standards require us to develop a false self rather than a true one [21]. As can be seen in the quotation above, psychology contradicts itself in the definition of "true self" because it makes its development dependent upon being in touch with other selves whose expectations cannot be met unless the "true self" becomes a "false self"! (It must be noted that the authority psychology quotes to substantiate its conceptualization and acceptance of true self, i.e., Laing, is a psychiatrist by profession!). In order to find out whether there is a "true self" in reality, Strohminger, Newman and Knobe (in press) conducted a research project and concluded that. The true self is, shall we say, evidence-insensitive. claims made on its behalf may completely contradict all available data, as when the hopelessly miserable and knavish are nonetheless deemed good 'deep down'. The true self is posited rather than observed. It is a hopeful phantasm in our view, it is a fiction nonetheless. (p. 7). In spite of having no evidence to prove the existence of true "self", psychiatry and psychology endorse false "self". Religion, however, characterizes a false "self" as a polytheist who yields knowingly to its caprices by exploiting other selves. Psychiatry and psychology call these caprices "id" and separate it from "self" so that it cannot be held responsible for what it does. This is done in the name of psychoanalysis.

Watson [37], for example, criticized Winnicott [38] because he introduced "the idea of a 'true self"' (p. 1). Watson believes that a true "self" represents "a return to an earlier, more narcissistic mode of thinking from which Freud enabled us to free ourselves" (p. 2). Although Watson does his best to deliver his readers from narcissism he traps them in determinism where their "id" rules their "ego", i.e., "self", rather than vice versa. In other words, instead of loving "self", they had better yield to their "id". He supports his argument by quoting Freud's [39] justification below. You over-estimated your strength when you thought you could treat your sexual instincts as you liked and could utterly ignore their intentions. The result is that they have rebelled and have taken their own obscure paths to escape this suppression; they have established their rights in a manner you cannot approve" (p. 3613).

According to religion, any "self" who yields to its "id" is "polytheistic" (Q20:16) whose most distinctive feature is holding selves other than itself responsible for its actions (Q75:2).

Watson [37], for example, agrees with Freud and challenges assigning any "self" to any given taxon such as "polytheistic" in order to render it irresponsible for what it does or feels. To support his position, he refers to Freud's [40,41] conversation with one of her patients called Elisabeth von R, respectively. her love for her brother-in-law was present in her consciousness like a foreign 
body, without having entered into relationship with the rest of her ideational life. With regard to these feelings, she was in the peculiar situation of knowing and at the same time not knowing.

'But if you knew you loved your employer why didn't you tell me?' - 'I didn't know - or rather I didn't want to know. I wanted to drive it out of my head and not think of it again; and I believe latterly [sic] I have succeeded.... 'Why is it that you were unwilling to admit this inclination? Where [sic] you ashamed of loving a man?' - 'Oh no, I'm not unreasonably prudish. We're not responsible for our feelings, anyhow. (p. 106)

As can be seen in the second quotation above Freud [40] did nothing but employ terms such as "ego" and "id" to support his patient's polytheistic self as reflected in her last response to Freud's question. [It must be mentioned that Watson [37] did not include the last four sentences quoted directly from Freud above]. Addressing Freud's question, "Were you ashamed of loving a man?" Elisabeth von R. replied, "We're not responsible for our feelings, anyhow" [41]. In other words, we as egos or "selves" are not responsible for our caprices or "id".

Through isolating a "self" from its "id" psychiatry and psychology arbitrarily absolves the "self" from any type of responsibility. Religion, however, not only integrates "id" in the instincts taxon of "self" but also holds it responsible for whatever its "id" does. Furthermore, instead of dividing a "self" into fictionary "false" and "true" individuals, religion places it in the self-theistic, polytheistic, and practicing monotheistic taxa as their willfully chosen diverse paths. They lead to the Judgment Day on which the taker of each path will witness its deeds (Q99:6). So, whosoever does a mote's weight of good shall see it (Q99:7). And whosoever does a mote's weight of evil shall see it (Q99:8).

\section{The seventh taxon of "self": The practicing monotheistic}

In contrast to the polytheistic, the monotheistic "self" brings its "id" under its control by either submitting to the rules set by God or by acquiring His attributes. Sex for the monotheistic "self" is, for example, an instinct which can be fulfilled only with a partner joined through marriage. Religion provides the prophet Joseph as a real example for a monotheistic self. An Egyptian power holder called Potiphar had bought Joseph from a slave market and wished to raise him as an honoured guest in his house. As a polytheistic "self" Zulaykhā, Potiphar's wife, however, falls in love with Joseph. "She indeed inclined toward him, and he would have inclined toward her, had he not seen the proof of his Lord" (Q12:24). The proof Joseph could see was two of God's attributes of the Hearing (e.g., Q2:127) and seeing (Q40:20) as described by Nasr et al. [29] below Zulaykhā, who worshipped idols, had covered an idol in the room. When Joseph asked her why she had done that, she replied by saying that she was ashamed to sin before the idol. Upon hearing this account, Joseph asked how she could be ashamed before an idol, which can neither see nor hear, but was not ashamed before God, who is Hearing and Seeing. This exchange led Joseph to contemplate his own situation before God, and this realization served as his proof (p. 1314).
Self-esteem is another feature of a practicing monotheistic "self". It is the first most important instinct in modern psychiatry and psychology because it has the highest tokens of 192 and 37 in their representative texts, respectively (see Appendix). The authorities in these fields believe that it is fulfilled largely by relating to external sources such as parents and analysts, e.g., "The idealized parental image leads to an idealizing transference, in which patients feel enhanced self-esteem by being in the presence of the exalted figure of the analyst" and "Alcoholism has serious effects on the 30 million children of people with this disorder. Home life for these children is likely to include much conflict and perhaps sexual or other forms of abuse. In turn, the children themselves have higher rates of psychological problems [42-44]. Many have low self-esteem, poor communication skills, poor sociability, and marital problems [21]. As can be seen in the quotations above psychiatry and psychology do emphasize the constructive role of models such as healthy parents to whom a "self" owes its bodily development and instincts such as "self-esteem". These fields also acknowledge the fact that the lack of a good model, e.g., missing or addict parents, results in low self-esteem in a "self". Religion does, however, not only establish but also emphasize another self, i.e. God's "self" whose role in fulfilling and enhancing all instincts is more important than any other selves including parents.

Religion, for example, refers to many characters who had gained instincts such as self-determination not through their parents but through practicing monotheism. Opposing his polytheistic father, the prophet Abraham, for example, asks, "Do you take idols for gods? Truly I see you and your people in manifest error" (Q6:74). He remains self-determined and breaks the idols even when he is threatened to be "stoned" (Q19:46) "killed" (Q29:24) or burned" (Q21:68). Modern psychiatry and psychology do bring up selfdeterminism (see the Appendix) but falls short of reporting a single case from religion.

\section{The last and highest taxon of "self": God's self}

Psychiatry and psychology assign no taxon for God in their treatment of "self". This might be due to their preoccupation with mental disorders than with mental health. This predisposition reveals itself best in the descriptions they provide for God in the tongue of their patients. Describing a schizophrenic, the former, for example, wrote "On one occasion, Ian", for example, "was found to be scratching himself with a kitchen knife in an effort to "please God". Similarly, psychology provides the case below. If he saw an arrow, he would follow the arrow interpreting it as a sign sent by God that he should go in that direction. Feeling lost and horrified, he would go home and stay there, afraid to go out because going out meant making decisions or choices that he felt unable to make $[21,45]$. Religion, however, views God as the one and only "self" (Q2:163) whose attributes are true. He, for example, lives forever (Q2:255) and is the only manifest truth (Q24:25) who is eternally sufficient unto Himself (Q112:2). Whoever believes in Him and follows His rules, i.e., the practicing monotheistic, and attains his attributes such as "righteousness" (Q52:28) and being "faithful and peaceful" (Q59:23) not only lives a healthy life in this world (e.g., Q6:82) but also attains eternal life with God upon death (Q3:169). 
And finally, similar to psychiatry and psychology, religion addresses mental disorders. However, instead of viewing disorders as discrete illnesses, religion assigns them to two taxa of "self", i.e., the selftheistic and polytheistic [46-48]. They are mentally sick (Q2:10; Q5:52; Q8:49; Q9:125; Q22:53; Q24:50; Q33:12; Q33:60; Q47:20; Q47:29; Q74:31) because they are "prodigal” (Q7:31), “commit adultery" (Q17:32), "consume the property of orphans unjustly" (Q4:10), "confound the truth with falsehood" (Q2:42), defraud (Q3:161), kill the practicing monotheistic without right (Q3:112), and "lie" (Q3:61), to name a few [49-52].

\section{Conclusion}

This study analyzed the texts representing psychiatry, psychology and religion because they share psyche as one of their main schema of study. The analysis showed that the first two fields have deliberately changed the main feature of psyche, i.e., soul, to "mind" in order to exclude religion from addressing mental health in general and mental disorders in particular. The findings also showed that religion provides more comprehensive features of "self" than psychiatry and psychology do. It also assigns them to eight taxa, i.e., body, instincts, cognition and emotion, psyche, the self-theistic, the polytheistic, the practicing monotheistic, and God's self. Then it describes what the practicing monotheistic do as the diagnostic features of mental health. The description of mental disorders via behaviours of the self-theistic and the polytheistic selves concludes the study.

\section{References}

1. Rumelhart DE (1980) Schemata: The building blocks of cognition. In: Spiro R, Bruce B, Brewer W (Eds.), Theoretical issues in reading comprehension. Lawrence Erlbaum Associates, Hillsdale, NJ, USA.

2. Ellis HC, Hunt RR (1993) Fundamentals of cognitive psychology. (5 edn), WCB Brown \& Benchmark Publishers, USA.

3. Khodadady E (1997) Schemata theory and multiple-choice item tests measuring reading comprehension (Unpublished doctoral dissertation). The University of Western Australia, Australia.

4. Khodadady E, Herriman M (2000) Schemata theory and selected response item tests: From theory to practice. In: Kunnan AJ (Eds.), Fairness and validation on language assessment. CUP, Cambridge, UK, pp. 201-222.

5. Khodadady E (2001) Schema: A theory of translation. In: Cunico S (Ed.), Training Translators and Interpreters in the New Millennium, Portsmouth $17^{\text {th }}$ March 2001 Conference Proceedings, Portsmouth, University of Portsmouth, England, UK, pp. 107-123.

6. Khodadady E (2013) Research principles, methods and statistics in applied linguistics. Hamsayeh Aftab, Mashhad, Iran.

7. Sadock BJ, Sadock VA, Ruiz P (2015) Kaplan \& Sadock's synopsis of psychiatry: Behavioral sciences/clinical psychiatry $\left(11^{\text {th }}\right.$ edn), Wolters Kluwer, Philadelphia, PA, USA.

8. Linnaeus C (1737) Hortus Cliffortianus. Amsterdam, Netherlands.

9. Azabdaftari B, Yaghmai P (1989) English for the students of Agriculture I, SAMT, Tehran.

10. Khodadady E, Ashrafborji M (2013) Motivations underlying English language learning and achievement. Sage Open 3(2): 1-8.
11. Gholamian M (2014) The factorial validity of motivations underlying English language learning among blind junior and senior high school students and its relationship with their English language achievement (Unpublished master's thesis). Ferdowsi University of Mashhad, Iran.

12. Hesarzadeh R (2013) The effect of schema-vs-translation-based instruction on $1^{\text {st }}$ grade Persian senior high school students' learning of English (Unpublished master's thesis). Ferdowsi University of Mashhad, Iran.

13. Yazdi BH (2015) Validation of a cultural intelligence scale in Iranian language institutes and exploring its relationship with learners' foreign language identity (Unpublished master's thesis). Ferdowsi University of Mashhad, Iran.

14.Dastgahian BS (2019) Quranic and shia ithna ashari religious orientations, life satisfaction, English language, and school achievement at pre-university (Unpublished PhD dissertation). Ferdowsi University of Mashhad, Iran.

15. Moosavi EG (2014) Validating a spiritual intelligence scale translated into Persian and exploring its relationship with grade three senior high school students' English achievement (Unpublished master's thesis). Ferdowsi University of Mashhad, Iran.

16. Lagzian M (2013) Textual analysis of an English dentistry text and its translation in Persian: A schema-based approach (Unpublished master's thesis). Ferdowsi University of Mashhad, Iran.

17. Milner M, Johannsen KL, Chase BT (2010) World English 2: Real people, real places, real language $\left(1^{\text {st }} \mathrm{edn}\right)$, Heinle Cengage Learning, UK.

18. Ascher A, Saslow J (2011) Top notch 2 (2 $2^{\text {nd }}$ edn), Pearson Longman, USA.

19. Oxenden C, Koenig LC (2008) American English file (1 $1^{\text {st }}$ edn), Oxford University Press, Oxford, UK.

20. Khodadady E, Shayesteh S (2016) Cultural and linguistic imperialism and the EIL movement: Evidence from a textbook analysis. Issues in Educational Research 26(4): 604-622.

21. Comer RJ (2015) Abnormal psychology. ( $9^{\text {th }}$ edn), Worth Publishers, New York, NY, USA.

22. World Population Review (2020) Muslim population by country 2020.

23. McAuliffe JD (2006) The Cambridge companion to the Quran. Cambridge University Press, Cambridge, UK.

24. Khodadady E, Dastgahian BS (2020) A scripture-specific religious orientation scale: Development and validation. Journal of Psychology and Mental Health Care 4(1): 1-13.

25. Khodadady E (2017) Microstructural translation of Al-Baqara (Q.2): A novel glimpse at its linguistic and ideological structure. Journal of Applied Linguistics and Language Research 4(4): 98-118.

26. Buckwalter T, Parkinson D (2011) A frequency dictionary of Arabic: Core vocabulary for learners. Routledge, London, UK.

27. Asad M (2011) The message of the Quran.

28. Ali M (1917) The Holy Quran containing the Arabic text with english translation and commentary. Surrey, Unwin Brothers, England.

29. Nasr SH, Dagli CK, Dakake MM, Lumbard JEB, Rustom M (2015) The study Quran: New translation with notes and commentary. New York, NY, USA

30. Yusuf Ali A (2011) The Quran: Translation \& Commentary Notes.

31. Al-Hilali, MT, Khan MM (1983) Translation of the meaning of the Noble Quran in the english language. King Fahd Complex for the Printing of the Holy Quran, Madina, Saudi Arabia.

32. Bussmann H (1996) Dictionary of language and linguistics. In: Trauth G, Kazzazi K (Eds.), Routledge, London, UK. 
33. Gilmore A (2000) A dictionary of the English Bible and its origins Sheffield Academic Press, Sheffield, England, UK.

34. Laing RD (1959) The divided self: An existential study in sanity and madness. Tavistock, London, UK.

35. Laing RD (1964) The divided self ( $2^{\text {nd }}$ edn), Pelican, London, UK.

36. Laing RD (1967) The politics of experience. Pantheon, New York, USA

37. Watson A (2014) Who am I? The self/subject according to psychoanalytic theory. SAGE Open 4(3): 1-14.

38. Winnicott DW (1960) Ego distortion in terms of true and false self. In: Winnicott DW (1965) The Maturational Processes and the Facilitating Environment: Studies in the theory of emotional development International Universities Press, New York, USA, pp. 140-153.

39. Freud S (1917) A difficulty in the path of psycho-analysis. In: Smith (2010) Freud-complete works. ( $\left.3^{\text {rd }} \mathrm{edn}\right)$, pp. 3606-3615.

40. Freud S (1895a) Studies on hysteria. Case 3: Miss Lucy R., age 30. In: Smith I (2010) Freud- complete works. ( $3^{\text {rd }}$ edn), pp. 95-110.

41. Freud S (1895b) Studies on hysteria. Case 5: History of fräulein Elisabeth von R. In: Smith I (Ed.), (2010) Freud-complete works. (3 ${ }^{\text {rd }}$ edn), pp. 121 145.

42. Kelley ML, Linden AN, Milletich RJ, Lau Barraco C, Kurtz ED, et al. (2014) Self and partner alcohol-related problems among ACOAs and nonACOAs: Associations with depressive symptoms and motivations for alcohol use. Addict Behav 39(1): 211-218.

43. Buu A, Wang W, Schroder SA, Kalaida NL, Puttler LI, et al. (2012) Developmental emergence of alcohol use disorder symptoms and their potential as early indicators for progression to alcohol dependence in a high-risk sample: A longitudinal study from childhood to early adulthood. Journal of Abnormal Psychology 121(4): 897-908.

44. Watt TT (2002) Marital and cohabiting relationships of adult children of alcoholics: Evidence from the national survey of family and households. Journal of Family Issues 23(2): 246-265.

45. Arieti S (1974) Interpretation of schizophrenia. Basic Books, New York, USA.

46. Freud S (1960) The origins of religion. Penguin Books, New Delhi, India.

47. Khodadady E, Dastgahian BS (2019) Relationship of subjective wellbeing and religiosity from theoretical and statistical perspectives. SOJ Psychology 6(1): 1-8.

48. Munn NL, Fernald LD, Fernald PS (1974) Introduction to psychology ( $3^{\text {rd }}$ edn), Mifflin, Boston: Houghton, USA.

49. Oxford Dictionary of Science ( $5^{\text {th }}$ edn), (2005) Oxford University Press, Oxford, UK.

50. Sadock BJ, Sadock VA, Ruiz P (2017) Kaplan \& Sadock's comprehensive textbook of psychiatry volume I/II $\left(10^{\text {th }}\right.$ edn). Philadelphia, PA: Wolters Kluwer.

51. Spinks GS (1963) Psychology and religion: An introduction to contemporary views. Beacon Press, Boston, USA.

52. Strohminger N, Newman G, Knobe J (2017) The True Self: A psychological concept distinct from the self. Perspectives on Psychological Science 12(4): 551-560.

For possible submissions Click below: 